\title{
Da sinnssykeloven var 86 år
}

\author{
I Tidsskriftet nr. 2/1934 er det et innlegg av den kjente «sinnssykelæge» Henrik Dedichen (1863-1935). På dette \\ tidspunkt i livet har han bare igjen å skrive sitt «psykiatriske testamente». Det han brenner for, er en ny sinns- \\ sykelov - med avskaffelse av kontrollkommisjoner uten psykiatrisk kompetanse. Eksistensen av disse kan \\ skyldes at selv «høit dannede mennesker» halvt ubevisst har en «mistillit til sinnssykelægen» og at dette «endog \\ har preget vår sinnssykelov» (Tidsskr Nor Lægeforen 1934; 54: 94-8). Kommisjonene eksisterer fortsatt...
}

\section{Klenodiet sinnssykeloven}

\author{
Av Henrik A. Th. Dedichen, Oslo.
}

Nous sommes tous plus ou moins atteints de misoneismus. Charcot.

Det er nu over 40 år siden jeg «kom på asyl» og jeg har siden uavbrudt vært knyttet til arbeidet med de sinnssykes kur og pleie, den siste menneskealder i samme anstalt. Det er jo alltid en stykke tid og arbeidet $\mathrm{i}$ en anstalt lar en opleve adskillig, som ellers ikke faller i lægens vei. Selv om man ikke er videre lærenem, kan det ikke undgåes, at man gjør sine erfaringer, og mine går nu i den retning, at fylkeslægens håp om og tro på at sinnssykelægenes kyndige innsikt skal bli mere erkjent og bedre forstått nu enn før kan jeg ikke dele. Der finnes selv hos - eller muligens nettop hos - tålelig høit dannede mennesker på bunnen av deres sjel en kanskje halvt ubevisst mistillit til sinnssykelægen, som formodes å ha en besynderlig næsten sadistisk farvet tilbøielighet til å gjøre alle mennesker sinnssyke, og så gammel er denne synsmåte, at den endog har preget vår sinnssykelov, uaktet at denne er skrevet av en læge, og det skal være visst, at det som i den bare er antydninger, berettigede den gang loven blev til, det har senere tids skrivebordsteoretikere forgrovet og forfusket.

Sinnssykeloven - den er av 17. august 1848. Dermed er i grunnen allting sagt. Siden den tid har både læren og pleien gjennemgått en utvikling så veldig, at man må ha gjort sig særlig fortrolig med den og helst så vidt mulig ha levd med den for helt ut å kunne vurdere den. Da Major begynte sin aldri nok berømte reformatorgjerning, forefant han tilstander så gruopvekkende, at man nu ikke vil tro dem mulige, $i$ et så vidt civilisert samfund som vårt dengang, og det stod derfor for ham som uundgåelig nødvendig å få måket Augiasstallen ren, så den aldrig mere blev istand til å vise sig i en tilnærmelsesvis lignende forfatning. Nu er alle hans bestemmelser forlengst ikke bare overflødige, men skadelige, fordi de hos den store hop levendeholder en dunkel forestilling om at de er nødvendige. Når loven således uttrykkelig forbyr legemlig refselse av de sinnssyke, er dette nu overflødig. Man kan naturligvis også i sinnssykepleien støte på uheldige individer ; men om nogen forløp sig således overfor de syke at han eller hun gikk til «legemlig refselse», vilde dette sikkert hurtig føre til vedkommendes avskedigelse. Det kunde ikke nu gå ubemerket hen.

(...)

Loven bestemmer at der ved hvert asyl skal være en kontrollkommisjon. Hensikten med den er at den skal være det store publikums vaktsomme øie, som med mistroens skjerpede blikk skal gå asylets drift efter i sømmene. Til veiledning for den er under 25. juli 1925 utstedt en instruks for den, og den bærer tydelig preg av å være skrevet av en ren Mussolini - selvfølgelig i hjemlig målestokk - som visstnok ikke lar sig begrense av foreliggende lover, men som allikevel ikke

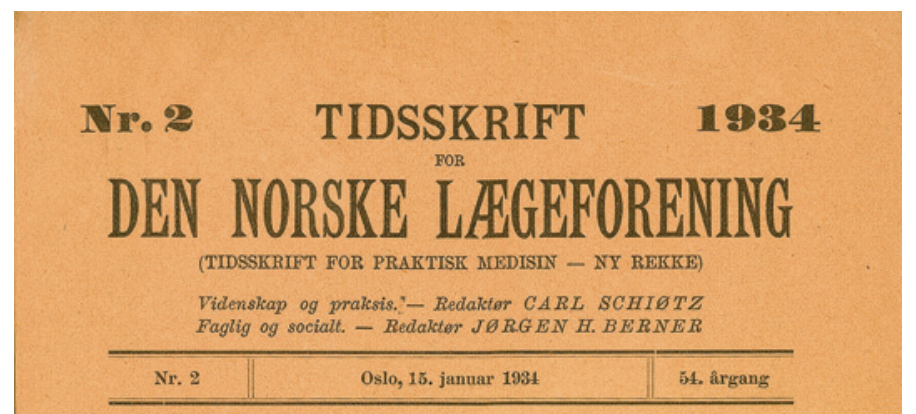

viser sig å være så faretruende stor. (...) Med de krav over sig, som denne instruks stiller, står kontrollkommisjonen overfor en uløselig opgave. Sett at man før en atlanterhavsdamper gikk av stabelen forlangte at den skulle besiktiges av en kommisjon bestående av en ingeniør, en stortingsmann og et kvinnelig medlem av stedets kommunestyre, - hvad vilde så derved være vunnet? Jeg mener at våre vanlige kontrollkommisjoner kommer ikke lengere med den såkalte sunde fornuft når det gjelder bedømmelsen av sinnssyke enn de vilde gjøre det overfor en veldig dampers sjødyktighet. Da jeg som ennu ganske ung kom fra min læretid hos Tysklands ypperste sinnssykelæge, syntes jeg det var en lett sak både å diagnostisere, prognostisere og behandle. $\mathrm{Nu}$ synes jeg det alt sammen er vanskeligere enn nogensinde.

(...)

Jeg har inntrykk av at når alle er like redde for å røre loven, er det fordi der er for mange som vil dele byttet. Fylke, kommune, stat, kontrollkommisjon, medisinalstyrelse og sakførere, ja til og med bladfolk vil ha sin del av kaken, så der blir ikke stort igjen til de sakkyndige. Derfor lar de heller den gamle dame leve til hun blir 100 år. Jo mere alderdomssvekket hun blir, desto lettere kan man forsyne sig av boet.

Jeg mener at jeg nu har gjort det som falt på min del i livet, og derfor har rett til å betrakte mig som en ferdig mann. Jeg har bare igjen å skrive mitt psykiatriske testamente. Det klarer sig vel uten vitterlighetsvidner, tenker jeg, for jeg har ikke noget annet å testamentere bort enn en fortreffelig lære :

Vi må ha en helt ny sinnssykelov, og den må bygges på den bærende tanke at de sinnssyke skal behandles som andre syke, så lenge ikke særegne forhold gjør særegne forholdsregler nødvendige. 